\title{
BIOPROSPECTION AND GENETIC DIVERSITY OF ENDOPHYTIC BACTERIA ASSOCIATED WITH CASSAVA PLANT ${ }^{1}$
}

\author{
MARIA CAMILA DE BARROS SILVA LEITE ${ }^{2 *}$, ARTHUR PRUDÊNCIO DE ARAUJO PEREIRA ${ }^{3}$, ADIJAILTON \\ JOSÉ DE SOUZA ${ }^{3}$, FERNANDO DINI ANDREOTE ${ }^{3}$, FERNANDO JOSÉ FREIRE ${ }^{4}$, JÚLIA KUKLINSKY SOBRAL ${ }^{2}$
}

\begin{abstract}
Cassava is mostly planted in sandy soils which are usually of low fertility, thereby making it necessary to perform beneficial associations with microorganisms that can promote their growth. In this perspective, the possibility of selecting bacterial isolates efficient in promoting the growth of the culture is evident, which can provide subsidies for future inoculants. The objective of this study was to isolate, identify, select and evaluate the genetic diversity of endophytic bacteria in roots and stems of cassava grown in Garanhuns - PE, with features involved in promoting plant growth. The isolation was performed on culture medium semisolid LGI-P. The selected isolates were evaluated for the potential to fix $\mathrm{N}_{2}$, as the ability to produce indole acetic acid, for their ability to solubilize inorganic phosphate and produce exopolysaccharides. Some bacterial isolates had their 16S rRNA gene sequenced by the Sanger method. A total of 52 endophytic bacteria isolates were obtained from cassava. Regarding the potential to fix $\mathrm{N}_{2}, 15 \%$ of the isolates were positive. As for the production of IAA, $78 \%$ of the isolates produced this phytohormone in a medium with increased L-tryptophan. Approximately $31 \%$ of the isolates were able to solubilize inorganic phosphate and $60 \%$ had exopolysaccharide. The identification of 19 isolates allowed the grouping into six bacterial genera, namely: Achromobacter, Bacillus, Burkholderia, Enterobacter, Pantoea and Pseudomonas. Cassava plants grown in Garanhuns - PE present interaction with different groups of endophytic bacteria and there are bacterial groups with several characteristics involved in promoting plant growth.
\end{abstract}

Keywords: 16S rRNA. Exopolysaccharide. Indole acetic acid. Biological nitrogen fixation. P solubilization.

\section{BIOPROSPECÇÃO E DIVERSIDADE GENÉTICA DE BACTÉRIAS ENDOFÍTICAS ASSOCIADAS A PLANTAS DE MANDIOCA}

\begin{abstract}
RESUMO - A mandioca é, geralmente, plantada em solos arenosos e de baixa fertilidade, tornando eminente a necessidade da mesma em realizar associações benéficas com micro-organismos que possam auxiliar seu crescimento. Nessa ótica, é evidente a possibilidade de seleção de isolados bacterianos eficientes em promover o crescimento da cultura, os quais podem fornecer subsídios para futuros inoculantes. O objetivo deste trabalho foi isolar, identificar, selecionar e avaliar a diversidade genética de bactérias endofíticas de raízes e caules de mandioca, cultivada em Garanhuns - PE, com características envolvidas na promoção de crescimento vegetal. $\mathrm{O}$ isolamento foi realizado em meio de cultura semissólido LGI-P. Os isolados selecionados foram avaliados quanto ao potencial de fixar $\mathrm{N}_{2}$, quanto à capacidade de produzir ácido indol acético, quanto à capacidade de solubilizar fosfato inorgânico e produzir exopolissacarídeos. Alguns isolados bacterianos tiveram o gene 16S rRNA sequenciados pelo método de Sanger. No total, foram obtidos 52 isolados de bactérias endofíticas de mandioca. Em relação ao potencial para fixar $\mathrm{N}_{2}, 15 \%$ dos isolados foram positivos. Quanto à produção de AIA, $78 \%$ dos isolados produziram este fitohormônio em meio com o acréscimo de L-triptofano. Cerca de $31 \%$ dos isolados foram capazes de solubilizar fosfato inorgânico e $60 \%$ apresentaram produção de exopolissacarídeos. A identificação de 19 isolados possibilitou o agrupamento em seis gêneros bacterianos, sendo eles: Achromobacter, Bacillus, Burkholderia, Enterobacter, Pantoea e Pseudomonas. Plantas de mandioca cultivadas em Garanhuns - PE apresentam interação com diferentes grupos de bactérias endofíticas e há grupos bacterianos com diversas características envolvidas na promoção de crescimento vegetal.
\end{abstract}

Palavras-chave: 16S rRNA. Exopolissacarídeo. Ácido indo acético. Fixação biológica de nitrogênio. Solubilização de P.

\footnotetext{
${ }^{\text {"Corresponding author }}$

${ }^{1}$ Received for publication in 10/18/2016; accepted in 05/16/2017.

Part of the first author monograph.

${ }^{2}$ Garanhuns Academic Unit, Universidade Federal Rural de Pernambuco, Garanhuns, PE, Brazil; camilabarross@gmail.com, jksobral@yahoo.com.br.

${ }^{3}$ Department of Soil Science, Escola Superior de Agricultura "Luiz de Queiroz", Universidade de São Paulo, Piracicaba, SP, Brazil; arthur.prudencio@usp.br, adijailtonjsouza@usp.br, fdandreo@gmail.com.

${ }^{4}$ Department of Agronomy, Universidade Federal Rural de Pernambuco, Recife, PE, Brazil; fernando.freire@ufrpe.br.
} 


\section{INTRODUCTION}

After sugarcane, cassava (Manihot esculenta Crantz) is the crop that produces the most calories per cultivated area and is therefore considered a source of carbohydrates, serving as food for millions of people (SILVEIRA; FREITAS, 2007). According to Jensen et al. (2015), it is high yielding and can meet part of the local demand, mainly in the semi-arid regions of the Brazilian Northeast.

Cassava is often cultivated in low fertility soils, but even under these conditions it is possible to obtain productivity levels around $8-12 \mathrm{t} \mathrm{ha}^{-1}$ (DEMEKE et al., 2014). This fact may be related, among other factors, to the close relationship between the crop and plant growth promoting bacteria (TEIXEIRA; MELO; VIEIRA, 2005). Thus, studies that evaluate the association of this plant with these microorganisms have become important, since they are used in the management of this crop.

Among the plant growth promoting bacteria (PGPB) are endophytic bacteria, which colonize the internal tissues of plants without damaging them (CASTRO-GONZÁLEZ et al., 2011). The promotion of plant growth by endophytic bacteria may be the result of indirect actions, such as suppression of diseases; or direct actions, such as the production of phytohormones, fixation of atmospheric nitrogen, solubilization of inorganic phosphate, among others (PEREIRA et al., 2012).

As a result of the high cost of nitrogen fertilizer and the risk associated with nitrogen (N) leaching into the watercourses, causing environmental degradation, the role of biological nitrogen fixation (BNF) is of utmost importance for the sustainable management of agriculture. In the same manner with BNF, emphasis has been placed on the selection of bacteria with production capacity for phytohormones, such as indole acetic acid (IAA) (PEREIRA et al., 2012), due to the plant growth regulating effect (TEIXEIRA et al., 2007).

Reinhardt et al. (2008), using molecular methods, confirmed the association of diazotrophic bacteria with cassava, where all the isolates presented positive hybridization with the nifH gene probe derived from Azospirillum brasilense.

In addition, because it is generally grown in low fertility soil, cassava can be deficient in phosphorus, an essential element in the generation of energy inside the plant, mainly in the form of ATP, besides forming cell walls and informative macromolecules such as DNA And RNA (DECHEN; NACHTIGALL, 2007). Therefore, a great interest has been generated by some bacteria that have the capacity to solubilize the phosphate present in the soil in non-labile forms and to make it available to the plants for the production and release of organic and inorganic acids (VASSILEV; VASSILEVA, 2003). In addition to these characteristics, the production of exopolysaccharides is very common in several genera of nitrogen-fixing bacteria, which may be associated with the formation of biofilms; and this is a fundamental mechanism during bacterial colonization (FERNANDES JÚNIOR et al., 2010; LIU et al., 2011).

Thus, the bioprospection of isolates with the ability to $\mathrm{BNF}$, to produce IAA, to solubilize inorganic $\mathrm{P}$ and to produce exopolysaccharides may help in understanding the mechanisms of bacterial-plant interaction and, consequently, to open new doors in the management of this culture. The objective of this work was to isolate, identify, select and evaluate the genetic diversity of the endophytic bacteria of roots and cassava stem, cultivated in Garanhuns - PE, with the characteristics involved in the promotion of plant growth.

\section{MATERIAL AND METHODS}

\section{Vegetable sample}

Vegetable samples were obtained from a non-commercial area cultivated with cassava from Garanhuns-PE ( $8^{\circ} 51^{\prime} 25^{\prime \prime} \mathrm{S}$ and $\left.36^{\circ} 27^{\prime} 31^{\prime \prime O}\right)$. This area was first cultivated with beans and corn for some years, with no fertilizer management, only stirring the soil with part of the plant material from the previous crop. After these crops, without previous fertilization, the cassava crop was cultivated in the area, and it was the second cultivated crop in the plot. Samples of stems and healthy roots of 10 cassava plants were collected during the first semester of 2009. The plant samples were collected at 16 months after planting (near the final cycle of the crop), and were identified and taken to the Laboratory of Genetics and Microbial Biotechnology (LGBM) of the Garanhuns Academic Unit / Federal Rural University of Pernambuco (UAG / UFRPE) for microbiological processing and analyses.

\section{Isolation of endophytic bacteria}

Initially, the samples were washed in running water to remove soil residues. Subsequently, they were sectioned into fragments of 8 to $12 \mathrm{~cm}$. These fragments were submitted for superficial disinfestation, which comprised of immersion in ethanol $70 \%$ for $1 \mathrm{~min}$, immersion in sodium hypochlorite solution $(2.5 \%)$ for $4 \mathrm{~min}$, immersion in ethanol $(70 \%)$ for $30 \mathrm{~s}$, followed by two sequential washes in deionized water (ARAÚJO et al., 2010). The disinfestation process was verified by the time of plating $100 \mu \mathrm{l}$ of the last wash water in Trypcase Soy Agar (TSA) rich culture medium.

Samples of $1 \mathrm{~g}$ of roots and $0.5 \mathrm{~g}$ of stem were cut into small fragments and macerated in a pre-sterile mortar. Next, the macerated material was inserted into centrifuge tubes containing $4 \mathrm{~mL}$ of phosphate buffered saline (PBS). After these steps, 
$100 \mu \mathrm{L}$ of each suspension (buffer + plant tissue) were plated in triplicate in Petri dishes discharged with semi-solid LGI-P culture medium, which is a medium rich in sucrose and acidic $\mathrm{pH}$, semi-selective for Gluconacetobacter diazotrophicus (DÖBEREINER; BALDANI; BALDANI, 1995), and incubated at $28^{\circ} \mathrm{C}$ for 7 days.

After growth, the films formed were scored in solid LGI-P medium (DÖBEREINER; BALDANI; BALDANI, 1995), plus $20 \mathrm{mg} \mathrm{L}^{-1}$ of yeast extract, incubated at $28^{\circ} \mathrm{C}$ for $7-10$ days. Thereafter, the colonies were purified by the technique of drainage strips. Pure colonies were stored at $4^{\circ} \mathrm{C}$ in P-potato medium (DÖBEREINER; BALDANI; BALDANI, 1995), and stored at $-20^{\circ} \mathrm{C}$ in a liquid LGI-P medium containing yeast extract plus $20 \%$ glycerol. Plant growth promotion tests were started shortly after isolation and were completed as soon as possible.

\section{Selection of bacteria with potential for the $\mathbf{N}_{2}$ fixation}

The isolates were inoculated using a platinum loop from isolated colonies in test tubes containing $13 \mathrm{~mL}$ of the sterile LGI-P medium, free of nitrogen source, according to Döbereiner, Baldani and Baldani, (1995), and incubated at $28^{\circ} \mathrm{C}$ for 10 days. The experiments were carried out in triplicates, with three consecutive peaks, and the positive result was qualitatively characterized by the formation of a horizontal orange halo inside the culture medium (PEREIRA et al., 2012).

\section{Selection of inorganic phosphate solubilizing bacteria in vitro}

To evaluate the potential of bacteria to solubilize inorganic phosphate in vitro, the isolates were inoculated using a platinum loop from isolated colonies in a solid medium containing dibasic calcium phosphate, modified according to Santos et al. (2012) and Silva et al. (2012). The plates were incubated at $28^{\circ} \mathrm{C}$ for $72 \mathrm{~h}$, and then the readings were taken. The experiments were carried out in triplicates and the presence of a clear halo around the colony indicated the solubilization of the phosphate.

\section{Selection of indole acetic acid producing bacteria (IAA)}

The IAA production test was performed using the colorimetric method, as described by Crozier et al. (1988) and Pereira et al. (2012). For this, isolated colonies were inoculated using a platinum loop in $25 \mathrm{~mL}$ of $10 \%$ TSA liquid medium, added with $5 \mathrm{mM}$ L-tryptophan, incubated under shaking $(120 \mathrm{rpm})$ at $28^{\circ} \mathrm{C}$ in the absence of light for $24 \mathrm{~h}$. Two milliliters of the bacterial culture suspension was centrifuged at $12,000 \mathrm{~g}$ for $5 \mathrm{~min}$. The supernatant was treated with the Salkowski reagent $\left(2 \% \mathrm{FeCl}_{3} 0.5 \mathrm{M}\right.$ in $35 \%$ perchloric acid) in the ratio of 1.5: 0.5 , and the reaction was incubated for $30 \mathrm{~min}$ at $28^{\circ} \mathrm{C}$ in the absence of light.

The experiments were carried out in triplicates and the positive result was characterized by the formation of a pink coloration of the medium. The strain EN303 (Pseudomonas oryzihabitans), endophytic soybean bacteria, auxin producer, inorganic phosphate solubilizer and $\mathrm{N}_{2}$-fixing agent (KUKLINSKY-SOBRAL et al., 2004) was used as positive control.

\section{Selection of exopolysaccharide-producing bacteria}

To verify the production of exopolysaccharide (EPS), the isolates were spiked in solid LGI-P medium (plus yeast extract), which is a nutrient medium rich in sucrose (suitable for the production of EPS by bacteria) incubated at $28^{\circ} \mathrm{C}$ for ten days, and then evaluated. The production of large, mucoid and elevated colonies indicated the production of exopolysaccharides, while flattened and dried colonies characterized the negative test.

\section{Isolates identification by $16 \mathrm{~S}$ rRNA gene sequencing}

For the partial sequencing of the $16 \mathrm{~S}$ rRNA gene, bacterial isolates $(n=19)$ were selected that presented characteristics involved in the promotion of plant growth, mainly in relation to their potential for $\mathrm{N}_{2}$ fixation, IAA production, and phosphate solubilization. The total DNA of the bacterial isolates was extracted according to Araújo et al. (2010). For extraction of the total DNA, the selected isolates were grown in TSB (Trypic Soy Broth) liquid medium for $24 \mathrm{~h}$, then $2 \mathrm{~mL}$ of the bacterial suspension was centrifuged at $10,000 \times \mathrm{g}$ for $2 \mathrm{~min}$ at $4^{\circ} \mathrm{C}$ and the supernatant was discarded. This step was repeated until the accumulation of a bacterial cell pellet. The bacterial cell pellet was resuspended in $500 \mu \mathrm{TE}(10 \mathrm{mM}$ Tris-HCl pH $8.1 \mathrm{mM}$ EDTA), added with $10 \mu \mathrm{l} 10 \%$ SDS and $100 \mathrm{mg}$ of $0.1 \mathrm{~mm}$ glass beads (Beads, Sigma) and subjected to homogenization and incubation at $80^{\circ} \mathrm{C}$ for $10 \mathrm{~min}$. Then the tubes were vortexed for $1 \mathrm{~min}$, and $500 \mu \mathrm{l}$ of phenol: chloroform $(1: 1, \mathrm{v}: \mathrm{v})$ were added and homogenized by inversion. Subsequently, the tubes were centrifuged at $10,000 \mathrm{~g}$ for $4 \mathrm{~min}$ at $4{ }^{\circ} \mathrm{C}$, and approximately $400 \mu \mathrm{L}$ of the upper phase of the microtube contents was transferred to a new microtube, adding $40 \mu \mathrm{L}$ of $3 \mathrm{M}$ sodium acetate (pH 5.2) and $400 \mu \mathrm{l}$ of isopropanol. The microtubes were then centrifuged at $10,000 \mathrm{~g}$ for $5 \mathrm{~min}$ at $5^{\circ} \mathrm{C}$, the supernatant discarded and the precipitate washed with $500 \mu \mathrm{l}$ of $80 \%$ ethanol, centrifuged again and the ethanol was discarded. The precipitate was then dried at $37^{\circ} \mathrm{C}$ and resuspended in $50 \mu \mathrm{TE}$, with DNA stored at $-20^{\circ} \mathrm{C}$ (ARAÚJO et al., 2010). The 
quality of the extracted product $(\sim 50 \mu \mathrm{L})$ was evaluated by means of $1.5 \%$ agarose gel electrophoresis, and the samples were subsequently stained in ethidium bromide solution and visualized under ultraviolet light.

Amplification of the V6 region of the $16 \mathrm{~S}$ rRNA gene was performed using the primers $027 \mathrm{~F}$ (5' GAGAGTTTGATCCTGGCTCAG 3') and 1387R (5' CGCTGTGTACAACGCCCGGGAACG $\left.3^{\prime}\right)$ and $1 \mu \mathrm{L}$ of the extracted DNA ( $\left.\sim 50 \mathrm{ng}\right)$. For this reaction, $32 \mu \mathrm{L}$ of sterile Milli-Q water was used; $4.1 \mu \mathrm{ldNTPs}(2.5 \mathrm{mM}), 7.5 \mu \mathrm{l} \mathrm{MgCl}_{2}(25 \mathrm{mM})$, $5.5 \mu \mathrm{l}$ Taq Buffer $(10 \mathrm{x}) ; 0.5 \mu \mathrm{l}$ of Taq DNA polymerase and $0.1(100 \mathrm{mM})$ of each primer. The reaction was performed in an Applied Biosystems Veriti ${ }^{\circledR}$ thermocycler with an initial denaturation of $94^{\circ} \mathrm{C}$ for $30 \mathrm{~s}, 30$ denaturation cycles at $94^{\circ} \mathrm{C}$ for $30 \mathrm{~s}$, primer annealing at $63^{\circ} \mathrm{C}$ for $1 \mathrm{~min}$ and extension at $72^{\circ} \mathrm{C}$ for $1 \mathrm{~min}$. After 30 cycles, the reaction was terminated with a final extension at $72^{\circ} \mathrm{C}$ for $10 \mathrm{~min}$. Each reaction had a final volume of $50 \mu \mathrm{L}$. About $5 \mu \mathrm{l}$ of the reaction product was checked on agarose gel $(1.2 \%)$ in $1 \mathrm{X}$ TAE buffer with the GebeRuler DNA Ladder (1 kb) marker at 20 volts $\mathrm{cm}^{-1}$, and then stained with a solution of GelRed TM (1000X) and photodocumented under ultraviolet light. PCR products were purified with the PureLink ${ }^{\circledR}$ PCR Purification Kit (Invitrogen), according to the instructions of the manufacturer. After purification, the amount of DNA in nanograms was estimated by comparison with the Mass Ruler Low Range DNA Ladder (Invitrogen), where it was possible to equimolarly adjust the PCR products to $50 \mathrm{ng} \mu \mathrm{L}^{-1}$. These samples were subjected to automated sequencing using the method of Sanger (SANGER; COULSON, 1975), the reverse primer 1387 (5 'CGGTGTGTACAACGCCCGGGAACG 3') was used as a basis for the sequencing reaction in the Genetic Analyzer ABI Prism377 (Applied Biosystems) apparatus.

The sequenced samples were analyzed using the CLC Genomics Workbench software (CLCbio, QIAGEN Company). The quality of the sequences was evaluated by the QualityTrimming tool, having sequences with Phred quality less than 20 and size less than 200 base pairs discarded from the subsequent analyses. Sequences with good quality were taxonomically affiliated through the RDP Classifier, and were compared by BLASTn (Basic Local Alignment Search Tool) against the NCBI database (National Center for Biotechnology Information - https://www.ncbi.nlm.nih.gov/).

\section{Statistical analysis}

The chi-square test $\left(\chi^{2}\right)$, with probability of $5 \%$, was used to verify the possible influence of the plant tissue on the bacterial expression of the evaluated characteristics. Sequences of the most similar bacterial isolates were used in the construction of phylogenetic trees by means of the software MEGA 4 (Molecular Evolutionary Genetics Analysis, version 4.0), using the coefficient of Jaccard statistic, being the reliability of the branches of the tree determined by bootstrap analysis (500 random sub-samples).

\section{RESULTS AND DISCUSSION}

\section{Isolation of endophytic bacteria}

Twenty-four bacterial isolates were obtained from stems and 28 cassava root isolates grown in Garanhuns - PE, totaling 52 isolates, which were named with acronyms ranging from G30 to G96. The isolates presented two types of morphology: i) orange color, dry appearance and without gum; and ii) orange, with a shiny and gummy appearance.

\section{Selection of $\mathrm{N}_{2}$-fixing bacteria}

Of the 52 bacterial isolates, eight presented potential for BNF (G32, G35, G41, G57, G66, G73, G84 and G95) since, after three consecutive peaks, they were able to grow in nitrogen-free culture medium. Reinhardt et al. (2008), working with cassava, also isolated the species of $\mathrm{N}_{2}$-fixing endophytic bacteria, expressing the characteristic of BNF. However, studies that identify these groups regarding other characteristics of growth promotion are also extremely important for later use in crop management.

It was observed that $50 \%$ of the $\mathrm{N}_{2}$ fixing bacteria came from the stem and 50\% from the root of cassava plants. All the fixative isolates basified the LGI-P culture medium, leaving it greenish (Figure 1).

According to Bhattacharjee, Singh and Mukhopadhyay (2008), the accumulation of nitrogen in the dry matter of non-leguminous plants is due not only to fertilization with mineral fertilizers, but also to a considerable fraction from the BNF carried out by endophytic and free-living organisms.

\section{Selection of inorganic phosphate solubilizing bacteria}

Of the 52 isolates tested, $31 \%$ were positive for the inorganic phosphate solubilization (G30, G31, G33, G34, G42, G49, G51, G64, G65, G67, G74, G75, G76, G78, G84 and G91) and presented the characteristic solubilization halo. Of these, $50 \%$ were from the stem and $50 \%$ from the cassava root, similar to that observed for the BNF characteristic. 


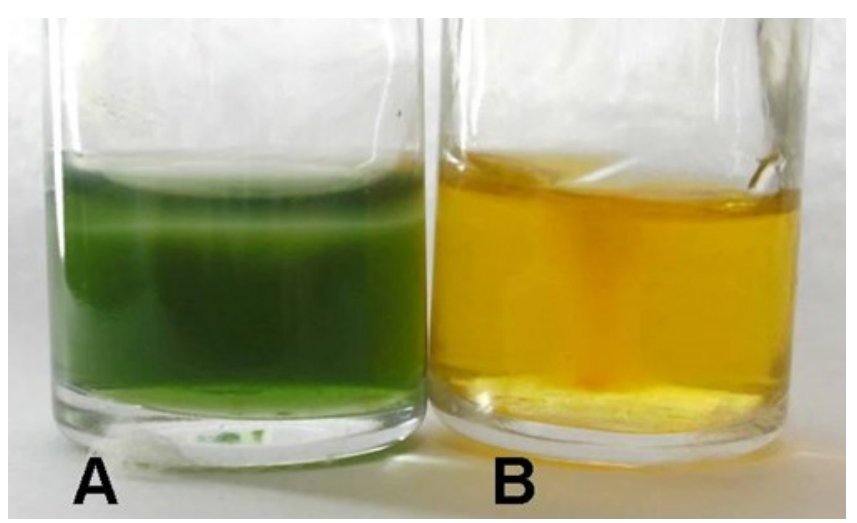

Figure 1. $\mathrm{N}_{2}$ fixation test in the LGI-P medium. A) Positive isolate, presenting a growth mist, in a basified medium; B) Negative isolate, absence of growth mist.

Solubilization of inorganic phosphate is a feature of high importance for the promotion of plant growth. Cassava crop needs about $0.005 \mathrm{mg} \mathrm{kg}^{-1}$ of available $\mathrm{P}$ in the soil solution, a quantity considered low when compared to other crops such as soybean, which requires $0.2 \mathrm{mg} \mathrm{kg}^{-1}$ of $\mathrm{P}$ (MENDES; JUNIOR, 2003). However, because it is cultivated in low fertility soils with low availability of $\mathrm{P}$, the presence of inorganic phosphate solubilizing bacteria is extremely important because they can provide the amount of $\mathrm{P}$ required by the plant. Thus, the bacterial isolates obtained in this work present a potential for use in the management of this crop, since they have the capacity to solubilize inorganic phosphate. However, in order to prove this potential, it is necessary to conduct experiments both in the greenhouse and in the field, with the inoculation of these bacteria in cassava plants.

Sungthongwises (2016), working with different plant species in Thailand, observed that the isolate obtained from cassava was able to solubilize phosphate from an insoluble source of $\mathrm{AlPO}_{4}$. While by its cultivation in a culture medium containing calcium phosphate source, solubilization was not observed, unlike the isolates obtained in this work. This shows that each isolate has its own characteristics, being influenced, among other things, by the place of cultivation. This demonstrates the importance of studying local isolates in order to handle the culture correctly in each environment.

\section{Selection of indole acetic acid producing bacteria (IAA)}

For the IAA production test, only the positive isolates for $\mathrm{BNF}$ and/or phosphate solubilization were tested. Thus, 23 isolates were evaluated, of which $78 \%$ produced IAA in a medium containing
L-tryptophan and $71 \%$ came from the roots of cassava plants. The positive reaction, observed by the pink coloration, presented a variation in the color intensity, being classified, according to the intensity of the pink coloration, as: low; medium and high. However, analysis by $\chi^{2}$ test revealed no influence at this intensity $(p<0.05)$.

By comparing the visual intensity of IAA production (Figure 2) with the plant tissue of the host plant, it was observed that the root provided the highest frequency of isolates with low yield, while the stem, the highest frequency with average yield $(p<0.05)$. However, cassava roots showed a higher percentage of positive isolates for the indole acetic acid (IAA) test. This may indicate that this bacterial group, even with low IAA production, interacted with this plant tissue of the host plant. In the work done by Teixeira et al. (2007) evaluated endophytic bacteria from roots, stems and leaves of different cassava varieties grown in the States of Amazon, Bahia and Sao Paulo, identified 47 species belonging to 27 genera, and Bacillus, Burkholderia, Enterobacter, Escherichia, Salmonella, Stenotrophomonas and Serratia the most frequent. Among them, Enterobacter cancerogenus, Stenotrophomonas maltophilia and Pseudomonas fluorescens, presented the potential to fix the atmospheric nitrogen and to produce IAA in vitro, as well as the isolates found in this work.

According to Teixeira et al. (2007), the use of IAA-producing bacteria or with potential for atmospheric nitrogen fixation is an initial form of selection of endophytes, since such characteristics require adequate conditions to express themselves. Therefore, the selection of bacteria expressing more than one trait involved in promoting plant growth will benefit inoculant development programs. 


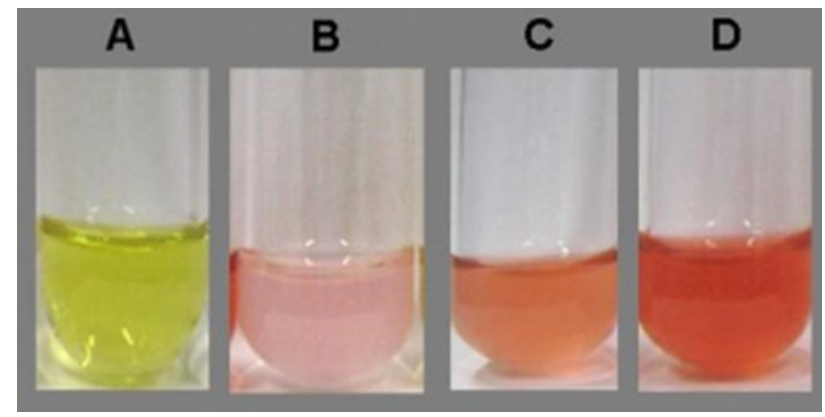

Figure 2. Color patterns were observed during the selection tests of indole acetic acid (IAA) bacteria. A) Negative control, culture medium without bacterial inoculum mixed with Salkowski's reagent; and bacterial culture mixed with Salkowski's reagent, production: B) low; C) average; D) high.

\section{Selection of exopolysaccharide-producing bacteria (EPS)}

It was observed that $60 \%$ of the endophytic bacteria of cassava produced exopolysaccharides, being G30, G31, G32, G33, G34, G37, G38, G40, G45, G46, G47, G53, G55, G58, G60, G61, G62, G67, G71, G73, G74, G75, G76, G79, G80, G82,
G83, G85, G86, G87 and G96. This production showed visual variation in its intensity, being classified as: non-producing, low production, medium production and high production (Figure 3 ). Of the positive isolates, $52 \%$ were from the root and $48 \%$ from the stem of cassava plants, and analysis by $\chi^{2}$ test revealed no influence on the treatments $(p<0.05)$.

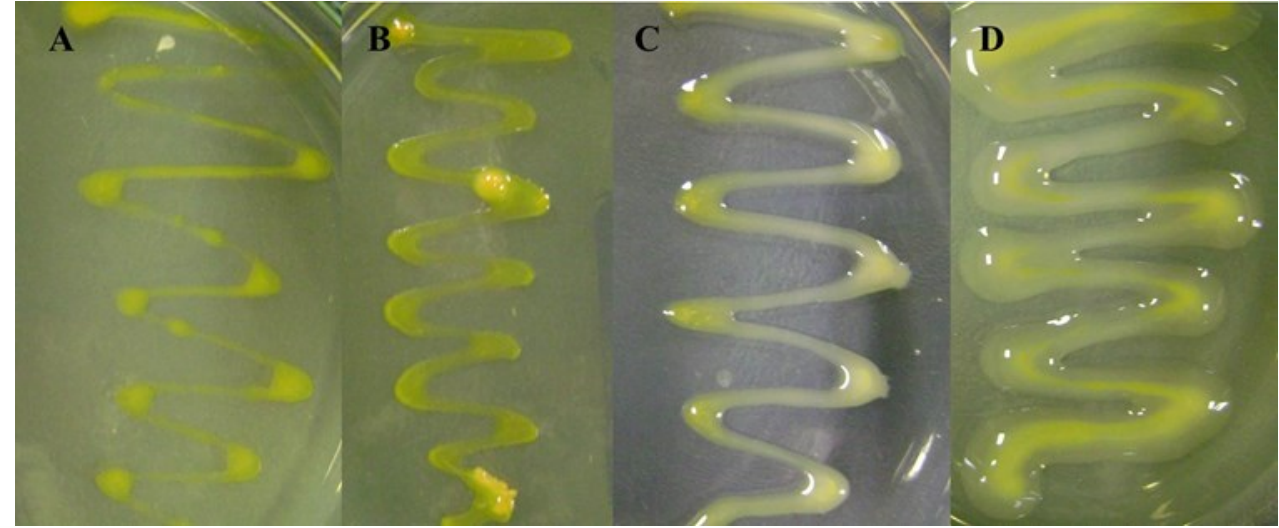

Figure 3. Views observed during the exopolysaccharide production test. A: Negative; B: Low production; C: Average yield; D: High production.

When comparing the visual intensity of EPS production with the plant tissue of the host plant, it was observed that the stem promoted a higher frequency of isolates with low production, while the root, the highest frequency with average production. This is probably due to bacterial colonization, which starts in large part at the root, and EPS can be a fundamental mechanism during this process, although EPS production can aid the microorganism's adhesion during colonization in a plant, thereby facilitating its proliferation (BOMFETI et al., 2011) prior to colonization.

Diniz et al. (2012), working with diazotrophic bacteria in soils under rubber tree, verified the presence of 17 EPS-producing isolates, evidencing the fact that bacteria that have characteristics involved with the promotion of plant growth may have benefits at the time of plant colonization, due to the production of EPS.

Therefore, for EPS-producing bacteria, a higher probability of colonization can be expected, obtaining more satisfactory results when it comes to bacterial isolates of interest for the promotion of plant growth.

It is noteworthy that of the 52 isolates evaluated, nine were positive for three characteristics evaluated and 11 for two. The selection of isolates with more than one characteristic of plant growth promotion has been receiving more attention from the researchers, due to the possibility of multiple functions in crop management programs (SHIOMI et al., 2009; LEITE et al., 2014).

Identification of isolates by sequencing the $16 \mathrm{~S}$ rRNA gene 
The identification of isolates G30, G31, G33, G34, G37, G42, G45, G47, G49, G53, G55, G57, G58, G61, G64, G65, G80, G83 and G87 with characteristics involved in promoting plant growth
(Table 1), showed similarity for the genera Achromobacter, Bacillus, Burkholderia Enterobacter, Pantoea and Pseudomonas (Table 2).

Table 1. Characteristics involved in promoting the plant growth of cassava isolates selected for sequencing of the $16 \mathrm{~S}$ rRNA gene.

\begin{tabular}{|c|c|c|c|c|}
\hline Isolates & $\mathrm{BNF}^{1}$ & $\mathrm{IAA}^{2}$ & Phosphate solubilization & $\mathrm{EPS}^{3}$ \\
\hline G30 & - & + & + & + \\
\hline G31 & - & + & + & + \\
\hline G33 & - & + & + & + \\
\hline G34 & - & + & + & + \\
\hline G37 & - & - & - & + \\
\hline G42 & - & + & + & - \\
\hline G45 & - & - & - & + \\
\hline G47 & - & - & - & + \\
\hline G49 & - & + & + & - \\
\hline G53 & - & - & - & + \\
\hline G55 & - & - & - & + \\
\hline G57 & + & + & - & - \\
\hline G58 & - & - & - & + \\
\hline G61 & - & - & - & + \\
\hline G64 & - & + & + & - \\
\hline G65 & - & + & + & - \\
\hline G80 & - & - & - & + \\
\hline G83 & - & - & - & + \\
\hline G87 & - & - & - & + \\
\hline
\end{tabular}

${ }^{1}$ Potential for nitrogen fixation (BNF), ${ }^{2}$ production of indole acetic acid (IAA), ${ }^{3}$ production of exopolysaccharides (EPS), (-) isolated with negative test result, $(+)$ isolated with positive test result.

The isolates identified as Enterobacter and Pantoea were in the same large group of genus of the database (Figure 4). For the isolate identified as Pseudomonas, the tree shows similarity with this bacterial genus (Figure 5), as well as the isolate identified as the genus Bacillus (Figure 6). As for the isolates identified as belonging to the genera Achromobacter and Burkholderia, there was a grouping with only species of the latter (Figure 7).

The endophytic bacterial diversity of cassava is evidenced not only in this work, however, in a study by Teixeira et al. (2007), in which several bacterial genera were identified, among them: Bacillus, Burkholderia, Enterobacter, Escherichia, Salmonella, Serratia and Stenotrophomonas. According to Teixeira, Melo and Vieira (2005), the genus Bacillus, Burkholderia, Enterobacter, Escherichia, Pseudomonas, Serratia, and Stenotrophomonas were the most frequent in cassava plants, some of which were positive for nitrogen fixation. 
Table 2. Similarity of the isolates with the bacterial genotypes found by BLAST against the NCBI database.

\begin{tabular}{|c|c|c|c|c|}
\hline Isolates & Subdivision & Family & Bacteria genus & Similarity (\%) \\
\hline G30 & & & Enterobacter & 99 \\
\hline G37 & & & Enterobacter & 99 \\
\hline G45 & & & Enterobacter & 98 \\
\hline G47 & & & Enterobacter & 100 \\
\hline G49 & & & Enterobacter & 100 \\
\hline \multirow[t]{2}{*}{ G55 } & & & Enterobacter & 98 \\
\hline & & Enterobacteriaceae & & \\
\hline G58 & Gamaproteobacteria & & Enterobacter & 99 \\
\hline G61 & & & Enterobacter & 99 \\
\hline G65 & & & Enterobacter & 97 \\
\hline G87 & & & Enterobacter & 99 \\
\hline G31 & & & Pantoea & 100 \\
\hline G34 & & & Pantoea & 99 \\
\hline G53 & & Pseudomonadaceae & Pseudomonas & 97 \\
\hline G33 & & & Achromobacter & 98 \\
\hline G42 & & Alcaligenaceae & Achromobacter & 97 \\
\hline G80 & Betaproteobacteria & & Achromobacter & 99 \\
\hline G57 & & & Burkholderia & 99 \\
\hline & & Burkholderiaceae & & \\
\hline G83 & & & Burkholderia & 100 \\
\hline G64 & Bacilli & Bacillaceae & Bacillus & 99 \\
\hline
\end{tabular}

Reinhardt et al. (2008), in a work with agricultural plants cultivated in the city of São Paulo - SP, including cassava, maize and sugar cane, identified known groups of nitrogen fixing bacteria, including the genera Azospirillum, Enterobacter, Herbaspirillum, Pseudomonas and Stenotrophomonas.

Therefore, there is a great diversity of endophytic bacterial species involved with cassava, and the present work found two genera that were not mentioned by the reported works, Achromobacter and Pantoea. In this way, investigations carried out in vitro help to select promising isolates to be tested (G30, G31, G33, G34, G67, G73, G75, G76 and G84). This study presents the most important characteristics of plant growth promotion. Later, in the field, these isolates can be evaluated in the form of inoculants, in programs of sustainable management of cassava in areas of low fertility. 


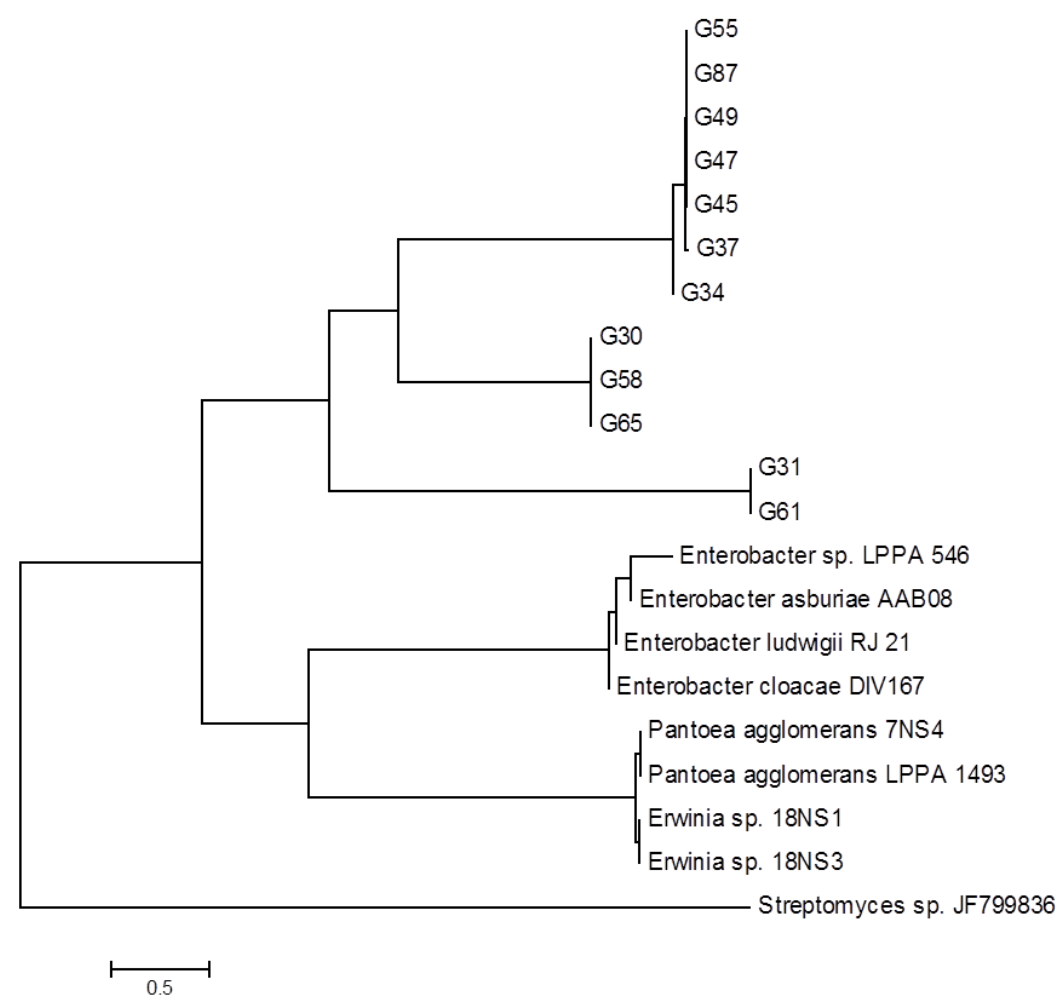

Figure 4. Gammaproteobacteria Subdivision Enterobacteriaceae family. Phylogenetic tree constructed by the MEGA 5.0 program through the $16 \mathrm{~S}$ rRNA sequences of the isolates G30, G31, G34, G37, G45, G47, G49, G55, G58, G6, G65 and G87, root endophytes and cassava stalk. The sequence of Streptomyces sp. was used to root the phylogenetic tree, as an outgroup.

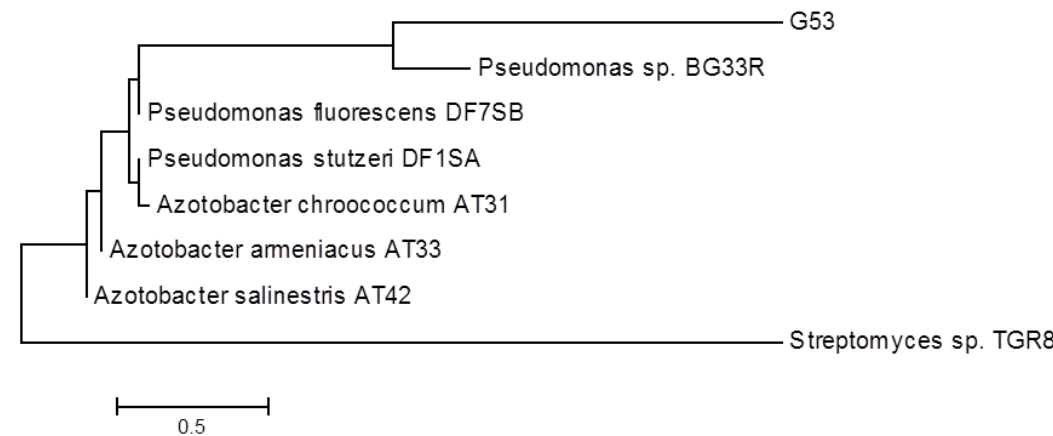

Figure 5. Gammaproteobacteria Subdivision, family Pseudomonadaceae. Phylogenetic tree constructed by the MEGA 5.0 program through the 16S rRNA sequences of the G53 isolate, endophytic cassava stem. The sequence of Streptomyces sp. was used to root the phylogenetic tree, as an outgroup.

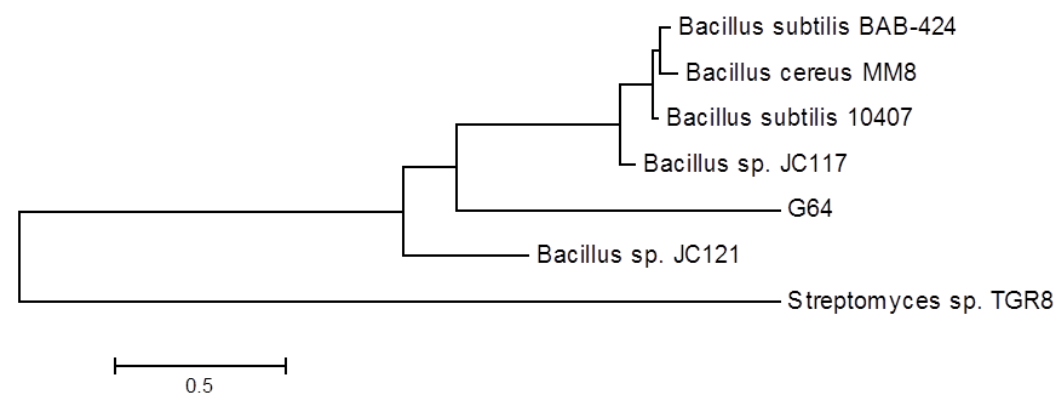

Figure 6. Bacilli subdivision, family Bacillaceae. Phylogenetic tree constructed by the MEGA 5.0 program through the sequences of $16 \mathrm{~S}$ rRNA sequences of the G64 isolate, endophytic cassava root. The sequence of Streptomyces sp. was used to root the phylogenetic tree, as an outgroup. 


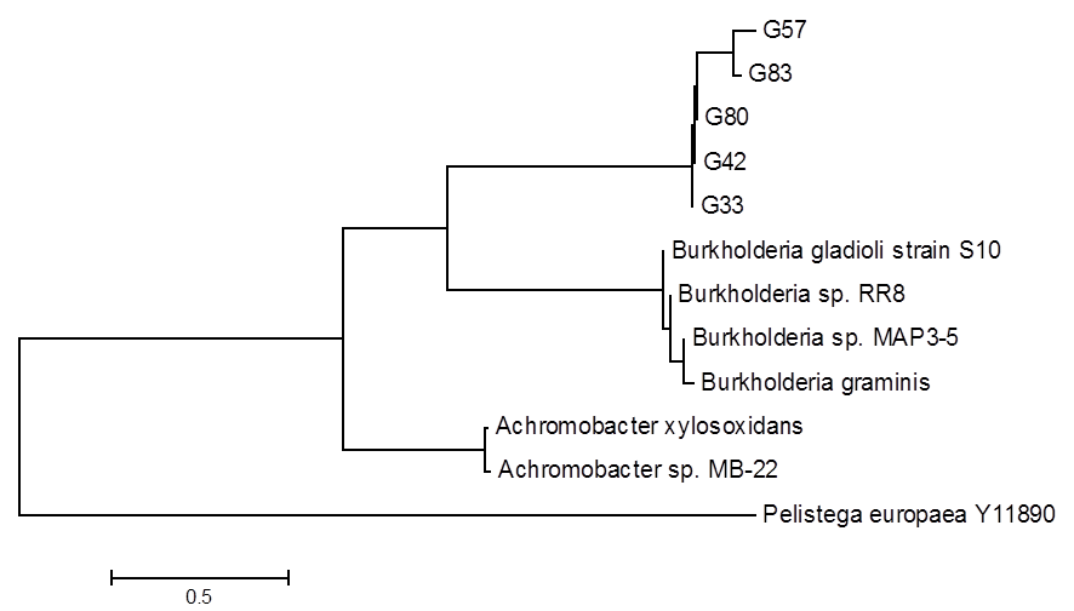

Figure 7. Betaproteobacteria Subdivision, family Alcaligenaceaee Burkholderiaceae. Phylogenetic tree constructed by the MEGA 5.0 program through the 16S rRNA isolates of the sequences G33, G42, G57, G80 and G83, root endophytes and cassava stalk. The Pelistega europaea sequence was used to root the phylogenetic tree, as an outgroup.

\section{CONCLUSION}

The endophytic bacteria of cassava plants presented potential plant growth promotion characteristics for in vitro tests such as BNF, phosphate solubilization, IAA production and EPS.

Cassava plants grown in Garanhuns - PE show interaction with endophytic bacteria in roots and stems, such as bacteria of the genus Acromobacter, Bacillus, Burkholderia, Enterobacter, Pantoea and Pseudomonas.

\section{REFERENCES}

ARAÚJO, W. L. et al. Guia prático: isolamento e caracterização de microrganismos endofíticos. 2. ed. Piracicaba, SP: CALQ, 2010. 167 p.

BHATTACHARJEE, R. B.; SINGH, A.; MUKHOPADHYAY, S. N. Use of nitrogen-fixing bacteria as biofertiliser for non-legumes: prospects and challenges. Applied Microbiology and Biotechnology, Wolverhampton, v. 80, n. 2, p. 199209, 2008.

BOMFETI, C. A. et al. Exopolysaccharides produced by the symbiotic nitrogen-fixing bacteria of leguminosae. Revista Brasileira de Ciência do Solo, Viçosa, v. 35, n. 3, p. 657-671, 2011.

CASTRO-GONZÁLEZ, R. et al. High diversity of culturable Burkholderia species associated with sugarcane. Plant and Soil, Perth, v. 345, n. 1, p. 155 $-169,2011$.

CROZIER, A. et al. Analysis of indole-3-acetic acid and related indoles in culture medium from Azospirillum lipoferum and Azospirillum brasiliense. Applied Microbiology and Biotechnology, Wolverhampton, v. 54, n. 11, p. 2833-2837, 1988.
DECHEN, A. R.; NACHTIGALL, G. R. Elementos requeridos à nutrição de plantas. In: NOVAIS, R. F. et al. (Eds.). Fertilidade do solo. Viçosa: Sociedade Brasileira de Ciência do Solo, 2007. cap. 3, p. 91132.

DEMEKE, Y. et al. Effects of plant growth regulators on in vitro cultured nodal explants of cassava (Manihot esculenta Crantz) clones. African Journal of Biotechnology, Victoria Island, v. 13, n. 28, p. 2830-2839, 2014.

DINIZ, P. F. A. et al. Bactérias diazotróficas em solos sobseringueira. Revista Brasileira de Ciência do Solo, Viçosa, v. 36, n. 5, p. 1426-1433, 2012.

DÖBEREINER, J.; BALDANI V. L. D.; BALDANI, J. I. Como isolar e identificar bactérias diazotróficas de plantas não-leguminosas. 1. ed. Brasília, DF: EMBRAPA-SPI, 1995. 60 p.

FERNANDES JÚNIOR, P. I. et al. Produção e comportamento reológico de exopolissacarídeos sintetizados por rizóbios isolados de guandu. Pesquisa Agropecuária Brasileira, Brasília, v. 45, n. 12, p. 1465-1471, 2010.

JENSEN, S. et al. Addition of cassava flours in bread -making: sensory and textural evaluation. LWT Food Science and Technology, Zürich, v. 60, n. 1, p. 292-299, 2015.

KUKLINSKY-SOBRAL, J. et al. Isolation and characterization of soybean-associated bacteria and their potential for plant growth promotion. Environmental Microbiology, Braunschweig, v. 6, n. 12 , p. 1244-1251, 2004.

LEITE, M. C. B. S. et al. Isolation, bioprospecting and diversity of salt-tolerant bacteria associated with sugarcane in soils of Pernambuco, Brazil. Revista 
Brasileira de Engenharia Agrícola e Ambiental, Campina Grande, v. 18, sup., p. 73-79, 2014.

LIU, X. et al. Characterization of two quorum sensing systems in the endophytic Serratiaplymuthica strain G3: differential control of motility and biofilm formation according to lifestyle. BMC Microbiology, London, v. 11, n. 26, p. 1-12, 2011.

MENDES, I. C.; JUNIOR, F. B. R. Microrganismos e disponibilidade de fósforo ( $P$ ) nos solos: uma análise crítica. 1. ed. Planaltina, DF: EMBRAPA CERRADOS, 2003. 26 p.

PEREIRA, A. P. A. et al. Salinity influence on the growth and production of indole acetic acid by endophytic Burkholderia spp. from sugarcane. Bioscience Journal, Uberlândia, v. 28, n. 1, p. 112 $121,2012$.

REINHARDT, É. L. et al. Molecular characterization of nitrogen-fixing bacteria isolated from Brazilian agricultural plants at São Paulo state. Brazilian Journal of Microbiology, São Paulo, v. 39, n. 3, p. 414-422, 2008.

SANGER, F.; COULSON, A. R. A rapid method for determining sequences in DNA by primed synthesis with DNA polymerase. Journal of Molecular Biology, London, v. 94, n. 3, p. 441-448, 1975.

SANTOS, I. B. et al. Bactérias diazotróficas associadas a raízes de cana-de-açúcar: solubilização de fosfato inorgânico e tolerância à salinidade. Bioscience Journal, Uberlândia, v. 28, n. 1, p. 142149, 2012.

SHIOMI, H. F. et al. Seleção de bactérias solubilizadoras de fosfato inorgânico, presentes em líquido ruminal bovino. Revista Brasileira de Agroecologia, Porto Alegre, v. 4, n. 2, p. 294-297, 2009.

SILVA, M. O. et al. Isolamento e prospecção de bactérias endofíticas e epifíticas na cana-de-açúcar em áreas com e sem cupinicida. Revista Brasileira de Ciência do Solo, Viçosa, v. 36, n. 4, p. 11131121, 2012.

SILVEIRA, A. P. D.; FREITAS, S. S. Microbiota do solo e qualidade ambiental. 1. ed. Campinas, SP: INSTITUTO AGRONÔMICO, 2007. 312 p.

SUNGTHONGWISES, K. Diversity of phosphate solubilizing bacteria under rubber intercropping. Asian Journal of Plant Sciences, Faisalabad, v. 15, n. 3-4, p. 75-80, 2016.

TEIXEIRA, M. A. et al. Microrganismos endofíticos de mandioca de áreas comerciais e etnovariedades em três estados brasileiros. Pesquisa Agropecuária Brasileira, Brasília, v. 42, n. 1, p. 43-49, 2007.

TEIXEIRA, M. A.; MELO, I. S.; VIEIRA, R. F. Ocorrência de bactérias diazotróficas endofíticas na mandioca (Manihot esculenta Crantz). 1. ed. Jaguariúna, SP: EMBRAPA MEIO AMBIENTE, 2005. 20 p.

VASSILEV, N.; VASSILEVA, M. Biotechnological solubilization of rock phosphateon media containing agro-industrial wastes. Applied Microbiology and Biotechnology, Wolverhampton, v. 61, n. 5, p. 435440, 2003. 